\title{
Efficacy and economics of certain new generation novel insecticides against legumepod borer, Maruca vitrata (Geyer) on pigeonpea (Cajanus cajan L.)
}

\author{
M Sreekanth*, M S M Lakshmi and Y Koteswara Rao \\ Regional Agricultural Research Station, Lam, Guntur - 522 034, India.
}

\section{ARTICLE INFO \\ Article history: \\ Received on: 15/05/2015 \\ Revised on: 10/06/2015 \\ Accepted on: 17/06/2015 \\ Available online: 20/06/2015 \\ Key words: \\ Insecticides, Maruca vitrata, Pigeonpea and Legume pod borer.}

\begin{abstract}
Two field experiments were conducted during Kharif, 2010 and 2011 to find out economical control measures against legume pod borer, Maruca vitrata (Geyer) on pigeonpea. Experimental results showed that the per cent inflorescence damage due to Maruca was lowest in chlorantraniliprole $18.5 \mathrm{SC}(2.08 \%)$ and flubendiamide 39.35 SC (3.64\%), followed by spinosad $45 \mathrm{SC}(6.21 \%)$ as against control $(31.18 \%)$ with 93.3 , 88.3 and 80.1 per cent reduction over control respectively. Similarly, pod damage due to legume pod borer was lowest in chlorantraniliprole $(4.30 \%)$, flubendiamide $(6.03 \%)$ and spinosad $(8.80 \%)$ as against control (47.28\%) with 90.9 , 87.3 and 81.4 per cent reduction over control respectively. Highest grain yield was recorded in chlorantraniliprole treated plots $(686.1 \mathrm{~kg} / \mathrm{ha})$ with 127.5 per cent increase over control, followed by flubendiamide $(595.8 \mathrm{~kg} / \mathrm{ha})$ and spinosad $(589.0 \mathrm{~kg} / \mathrm{ha})$ with 97.6 and 95.3 per cent increase over control $(301.6 \mathrm{~kg} / \mathrm{ha})$ respectively. The cost effectiveness of chlorantraniliprole and flubendiamide was also high and very favorable with incremental costbenefit ratios of 1: 4.64 and 1: 4.50 respectively, followed by indoxacarb (1: 3.67$)$, emamectin benzoate (1: 3.13$)$ and spinosad (1: 2.97).
\end{abstract}

\section{INTRODUCTION}

Pigeonpea (Cajanus cajan L) is a tropical grain legume mainly grown in India and ranks second in area and production and contributes about $90 \%$ in the world's pulse production. In India, pigeonpea is grown in 4.42 million ha with an annual production of 2.89 million tonnes and $655 \mathrm{~kg} \mathrm{ha}^{-1}$ of productivity. In Andhra Pradesh, it is cultivated in an area of 6.38 lakh ha with 2.65 lakh tonnes of production and with productivity of $415 \mathrm{~kg}$ $\mathrm{ha}^{-1}$ [1]. Though the area under redgram is increasing both in Kharif and Rabi seasons, the yields have remained stagnant (500$700 \mathrm{~kg} / \mathrm{ha}$ ) for the past 3-4 decades, largely due to insect pest damage [2]. More than 300 species of insect species have been reported infesting the crop [3] of which legume pod borer, Maruca vitrata is a serious pest of pigeonpea in tropic and subtropics, because of its extensive host range, destructiveness and distribution on cowpea, mungbean, urdbean and field bean [4]. The infestation levels range from 9-51\% [5], whereas 84 per cent pod borer damage in pigeonpea [6]. The annual loss was estimated to be US $\$ 30$ million [7]. The larvae feed on flowers, buds and pods and the entrance hole is plugged with excreta. It is

\footnotetext{
* Corresponding Author

Email: meragana.angrau [at gmail.com
}

basically a hidden pest and completes its larval development inside the web formed by rolling and tying together leaves, flowers, buds and pods. This typical concealed feeding protects the larvae from natural enemies, human interventions or other adverse factors including insecticides [8]. Considerable numbers of insecticides have been tested and few of them found effective against legume pod borer in pigeonpea [9]; [10]. Repeated use of these insecticides also resulted in the development of resistance. Insecticides that should leave lesser residues and pose lesser environmental threat has become imperative. The present study is aimed at evaluating the efficacy of certain new insecticides with novel mode of action for effective management of the legume pod borer, Maruca vitrata on pigeonpea.

\section{MATERIALS AND METHODS}

The experiments were conducted during Kharif, 2010 and 2011 at Regional Agricultural Research Station, Lam, Guntur. Emmamectin benzoate 5 SG, spinosad 45 SC, indoxacarb 14.5 SC, chlorantraniliprole $20 \mathrm{SC}$, flubendiamide $480 \mathrm{SC}$, novaluron 10 EC, profenofos 50EC along with an untreated control (Table 1) were tried against legume pod borer, M. vitrata on a pigeonpea cv. ICPL 85063 (Lakshmi). There were three replications (4 rows of 
$5 \mathrm{~m}$ long in each replication) in a randomized block design (RBD). The seeds were sown at a depth of $5 \mathrm{~cm}$ below the soil surface in black cotton soils with the help "gorru" behind the cattle pair with $180 \mathrm{~cm}$ spacing between rows. Immediately after sowing "guntaka" was run over the seeds to cover the seeds with soil. Thinning was done 20 days after seedling emergence by retaining one seedling per hill at a spacing of $20 \mathrm{~cm}$ between the plants Normal agronomic practices were followed for raising the crop (Basal fertilizer N: P: K: 20:50: $0 \mathrm{~kg} / \mathrm{ha}$ ). Intercultural and weeding operations were carried out as needed.

Three sprays were applied commencing at 50 per cent flowering, second at pod initiation stage and last at 50 per cent podding stage with hand operated knapsack sprayer with a spray volume of 500 lts per ha. Twenty five inflorescences $(30 \mathrm{~cm}$ length) were selected at random in each plot from the middle two rows for the observations on per cent inflorescence damage due to Maruca vitrata. At maturity, number of pods showing $M$. vitrata damage was recorded and expressed as a percentage of the total number of pods. All the pods were threshed and grain yield was recorded after discarding the $M$. vitrata damaged grains. This method was uniformly followed for both the seasons.

The monetary returns and incremental cost-benefit ratios of treatments were also worked out for selecting economical treatments against the pest. The data was subjected to RBD analysis using AGRES package [11].

\section{RESULTS AND DISCUSSION}

During 2010, inflorescence damage due to legume pod borer larvae was significantly reduced in plots treated with chlorantraniliprole $(2.3 \%)$, flubendiamide $(3.1 \%)$ and spinosad (5.2\%) when compared to control (28.1\%) (Table 1). Chlorantraniliprole maintained its superiority during 2011 too, with 1.9 per cent inflorescence damage as against 34.3 per cent in the control.

The mean per cent inflorescence damage after two seasons was also found to be significantly low in plots treated with chlorantraniliprole (2.1\%) and flubendiamide (3.6\%), followed by spinosad (6.2\%), while $31.2 \%$ damage was noticed in the untreated control. Similarly, the pod damage due to legume pod borer was significantly reduced in plots treated with chlorantraniliprole (8.3\%), flubendiamide $(11.6 \%)$ and spinosad $(14.3 \%)$ than the control $(68.3 \%)$ (Table 1).

Chlorantraniliprole, flubendiamide and spinosad maintained their superiority during 2011 too, with $0.3,0.4$ and 3.3 per cent pod damage respectively as against 26.3 per cent in the control. The mean per cent pod damage after two seasons was also found to be significantly low in plots treated with chlorantraniliprole $(4.3 \%)$, flubendiamide $(6.0 \%)$ and spinosad $(8.8 \%)$, while $47.3 \%$ damage was noticed in the untreated control.

Continuous heavy rains during August and September, 2010 have resulted in heavy vegetative growth and the rains received during October and December, 2010 have resulted in heavy flower drop (both first and second flesh) which has resulted in drastic reduction in the yield. However, maximum yield of $743.1 \mathrm{~kg} / \mathrm{ha}$ was obtained in plots treated with chlorantraniliprole, followed by flubendiamide $(630.5 \mathrm{~kg} / \mathrm{ha})$ and spinosad $(622.0$ $\mathrm{kg} / \mathrm{ha}$ ) as against the lowest yield of $324.1 \mathrm{~kg} / \mathrm{ha}$ in untreated check during 2010 (Table 2). The erratic rainfall pattern during the crop growth period has resulted in poor yields during 2011-12. However, chlorantraniliprole maintained its superiority during 2011 too, with maximum yield of $629.1 \mathrm{~kg} / \mathrm{ha}$ as against 279.0 $\mathrm{kg} / \mathrm{ha}$ in control.

Pooled data revealed that highest grain yield was recorded in chlorantraniliprole treated plots $(686.1 \mathrm{~kg} / \mathrm{ha})$ with 127.5 per cent increase over control, followed by flubendiamide $(595.8 \mathrm{~kg} / \mathrm{ha})$ and spinosad $(589.0 \mathrm{~kg} / \mathrm{ha})$ with 97.6 and 95.3 per cent increase over control respectively as against the minimum yield of $301.6 \mathrm{~kg} / \mathrm{ha}$ in the untreated check (Table 2).

The cost effectiveness of chlorantraniliprole and flubendiamide was also high and very favorable with incremental cost-benefit ratios of 1: 4.64 and 1: 4.50 , respectively, followed by indoxacarb (1: 3.67) (Table 2).

Since the insecticides were new, the results available on different crops were presented and discussed here. The results obtained in the present investigation were in agreement with the findings of [12], who reported that chlorantraniliprole $(0.009 \%)$ recorded least pod damage (1.6\%) due to M. vitrata on pigeonpea than control (5.3\%). Flubendiamide 24\% + thiacloprid 24-48\% SC recorded high larval population reduction (84.45\%) in M. testulalis on blackgram [13]. Pod damage due to legume pod borer, $M$. vitrata was lowest in plants sprayed with spinosad $(8.5 \%)$ and indoxacarb (11.8\%); and also registered lowest seed damage (3.9 and $3.7 \%$, respectively) and highest grain yield (795 and 688 $\mathrm{kg} / \mathrm{ha}$ ) [14]. Lower pod damage due to $M$. vitrata with spinosad 90g, spinosad $73 \mathrm{~g}$, spinosad $56 \mathrm{~g}$ and spinosad $45 \mathrm{~g}$ a.i/ha, as against other standard insecticides was reported [15]. Novaluron offered moderate suppression of the pest and recorded $30.7 \%$ pod damage in cowpea [16]. Studies conducted at Regional Agricultural Research Station, Lam farm during 2002 revealed that novaluron@75 g a.i. ha-1 was found to be very effective in reducing the $M$. vitrata pod damage in blackgram and redgram by recording 0.4 and $2.2 \%$ respectively [17].

Application of $1000 \mathrm{ml}$ profenofos per ha + lufenuron resulted in the lowest pod damage $(10.0 \%)$, grain damage by pod borer $(0.7 \%)$ and the highest yield $(1618.3 \mathrm{~kg} / \mathrm{ha})$ in pigeonpea [18]. The effectiveness of emamectin benzoate, which was based on green chemistry, will help in achieving less yield losses through reduction in $H$. armigera incidence in pigeonpea [19].

The present findings clearly indicated that the new generation novel insecticides like chlorantraniliprole, flubendiamide and spinosad were found effective against legume pod borer, Maruca vitrata along with an increased level of yield. Further, the incremental cost benefit ratio was also more with chlorantraniliprole (1: 4.64) and flubendiamide (1: 4.50). Hence, it is suggested that the effective insecticides may be alternated in order to avoid the development of resistance. 
Table 1: Efficacy of insecticides against legume pod borer, Maruca vitrata on pigeonpea.

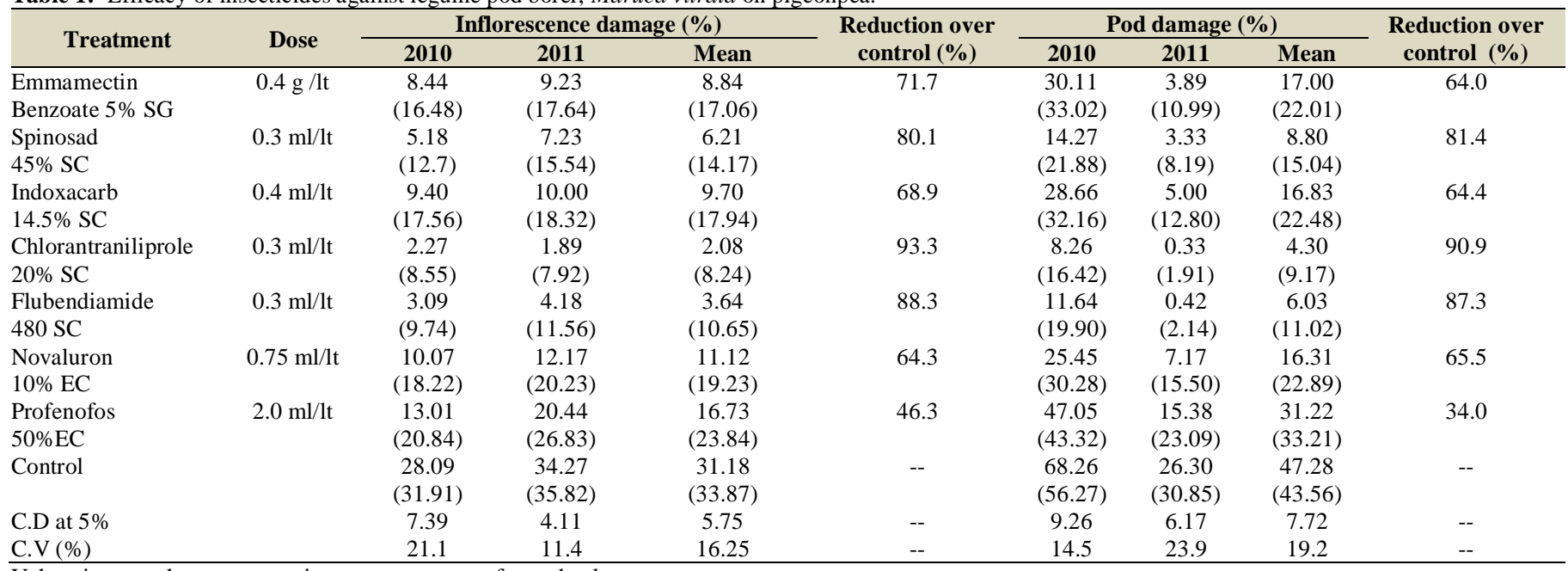

Values in parentheses are arc sine percentage transformed values.

Table 2: Economics of certain new insecticides against legume pod borer, Maruca vitrata in pigeonpea.

\begin{tabular}{|c|c|c|c|c|c|c|c|c|c|c|}
\hline Treatment & Dose & \multicolumn{3}{|c|}{ Yield $(\mathrm{kg} / \mathrm{h})$} & $\begin{array}{c}\text { Increase in } \\
\text { Yield over } \\
\text { control } \\
(\mathrm{kg} / \mathrm{ha})\end{array}$ & $\begin{array}{c}\text { Increase in } \\
\text { yield } \\
\text { over control } \\
(\%)\end{array}$ & $\begin{array}{c}\text { Cost of } \\
\text { Increased } \\
\text { yield (Rs.) } \\
\text { [A] }\end{array}$ & $\begin{array}{c}\text { Cost of } \\
\text { Plant } \\
\text { Protection } \\
\text { (Rs.)[B] }\end{array}$ & $\begin{array}{c}\text { Net Profit } \\
\text { (Rs.) } \\
\text { [A-B] }\end{array}$ & ICBF \\
\hline $\begin{array}{l}\text { Emmamectin } \\
\text { Benzoate 5\% SG }\end{array}$ & $0.4 \mathrm{~g} / \mathrm{lt}$ & 550.9 & 529.0 & 540.0 & 238.4 & 74.1 & 9536.00 & $2310-00$ & $7226-00$ & $1: 3.13$ \\
\hline Spinosad $45 \%$ SC & $0.3 \mathrm{ml} / \mathrm{lt}$ & 622.0 & 556.0 & 589.0 & 287.5 & 95.3 & 11500.00 . & $2900-00$ & $8600-00$ & $1: 2.97$ \\
\hline $\begin{array}{l}\text { Indoxacarb } \\
14.5 \% \mathrm{SC}\end{array}$ & $0.4 \mathrm{ml} / \mathrm{lt}$ & 555.5 & 421.0 & 488.3 & 186.7 & 61.9 & 7468.00 & $1600-00$ & $5868-00$ & $1: 3.67$ \\
\hline $\begin{array}{l}\text { Flubendiamide } \\
480 \mathrm{SC}\end{array}$ & $0.2 \mathrm{ml} / \mathrm{lt}$ & 630.5 & 561.1 & 595.8 & 294.3 & 97.6 & 11772.00 & $2140-00$ & $9632-00$ & $1: 4.50$ \\
\hline Novaluron $10 \%$ EC & $1.0 \mathrm{ml} / 1 \mathrm{t}$ & 546.3 & 398.0 & 472.2 & 170.6 & 56.6 & 6824.00 & $2450-00$ & $4374-00$ & $1: 1.79$ \\
\hline Profenofos $50 \%$ EC & $2.0 \mathrm{ml} / \mathrm{lt}$ & 445.4 & 376.0 & 410.7 & 109.2 & 36.2 & 4368.00 & $1245-00$ & $3123-00$ & $1: 2.51$ \\
\hline Control & & 324.1 & 279.0 & 301.6 & -- & -- & -- & -- & -- & -- \\
\hline C.D at $5 \%$ & & 111.62 & 65.78 & 88.7 & -- & -- & -- & -- & -- & -- \\
\hline C.V $(\%)$ & & 14.3 & 10.1 & 12.20 & -- & -- & -- & -- & -- & -- \\
\hline
\end{tabular}

Market Price of Redgram: Rs. 40/- per kg; Standard spray volume: 500 1/ha

\section{REFERENCES}

1. All India Co-ordinated Research Project on Pigeonpea. Project Coordinator's Report. 2012; 9 -10.

2. Sharma H C and Pampapathy G. Effect of natural plant products, Brassinolide and host plant resistance in combination with insecticides on Helicoverpa armigera (Hubner) damages in pigeonpea. Indian Journal of Plant Protection. 2004; 32 (2): 40-44

3. Lal, S.S. and Singh, N.B. In Proceedings of National Symposium on Management of Biotic and Abiotic Stresses in Pulse Crops. Indian Institute for Pulse Research, Kanpur, India. 1998; 65-80

4. Shanower T G, Romeis J and Minja E M. Insect pests of pigeonpea and their management. Annual Review of Entomology. 1999;44:77-96

5. Vishakantaiah $\mathrm{M}$ and Jagadeesh Babu C S. Bionomics of the tur webworm, Maruca testulalis (Lepidoptera : Pyralidae). Mysore Journal of Agricultural Sciences. 1980; 14: 529-532.

6. Darmasena S M D, Subasinghe S M C, Lateef S S, Menike S, Saxena K B and Ariyaratne H P. In: Pigeonpea - Varietal Adaptation and production studies in Sri Lank, Report of Work. Department of Agriculture, Sri Lanka, ICRISAT, Patancheru, Andhra Pradesh, India. Entomology Research. 1992; 104-108.

7. Saxena K B, Chandrasena G D S N, Hettiarachchi K, Iqbal Y B, Fonseka H H D and Jayasekara S J B A. Evaluation of pigeon pea accessions and selected lines for reaction to Maruca. Crop Science. 2002; 42: 615-618.
8. Sharma H C. Bionomics, host plant resistance and management of legume pod borer, Maruca vitrata - a review. Crop Protection. 1998; 17: 373-386.

9. Saxena K B, Hettiarachchi K, Chandrasena G D S N, Iqbal Y B, Bhagwat V R, Fonseka H M D, Joseph K D S M and Lal S S. Breeding pigeonpeas for resistance to Maruca vitrata. Paper presented at Symposium on biotic and abiotic stresses in pulses 26-28 June 1998, Indian Institute of Pulses Research, Kanpur.1998.

10. Sahoo B K and Senapathi B. Comparative efficacy of synthetic insecticides and plant products against the incidence of pigeonpea pod borers. Indian Journal of Plant Protection. 2000; 28: 29-34.

11. Gomez K A and Gomez A A. Statistical procedures for agricultural research. Joh Wiley and sons, New York, 1984; 207-215

12. Haritha B. Biology and management of Maruca vitrata (Geyer) in pigeonpea. M.Sc(Ag) Thesis. Acharya N G Ranga Agricultural University, Hyderabad, India. 2008.

13. Shivaraju C, Ashok kumar C T, Sudhirkumar S and Thippaiah M. Efficacy of indigenous materials and new insecticide molecules against Maruca testulalis (Hubner) on blackgram. International Journal of Plant Protection. 2011; 4(1): 214-216.

14. Rao G V R, Kumari P R A, Rao V R and Reddy Y V R. Evaluation of spinosad and indoxacarb for the management of legume pod borer, Maruca vitrata (Geyer) in Pigeonpea. Journal of food legumes. 2007; 20(1): 126-127. 
15. Mittal V and Ujagir R.. Evaluation of naturalyte spinosad against pod borer complex in early pigeonpea. Indian Journal of Plant Protection. 2005; 33 (2): 211-215.

16. Chandrayudu E, Srinivasan S and Venugopal Rao N. Evaluation of certain new insecticides against spotted pod borer, Maruca vitrata in cowpea. Indian Journal of Plant Protection. 2006; 34 (1): 118-119.

17. All India Coordinated Research Project on Pulses. RARS report for 2002-03, Lam farm, Guntur, Andhra Pradesh, India. 2003.

18. Chandrakar $\mathrm{H}$ K and Shrivastava S K.. Evaluation of some combinations of match (Lufenuron) against pod damaging pests in pigeonpea. Journal of Applied Zoological Researches. 2002; 13 (2/3): 206-207.
19. Sharma OP, Bhosle BB, Kamble KR, Bhede BV and Seeras NR. Management of pigeonpea pod borers with special reference to pod fly (Melanagromyza obtusa). Indian Journal of Agricultural Sciences. 2011; 81(6): 539-543

\section{How to cite this article:}

Sreekanth M, Lakshmi M S M and Koteswara Rao Y. Efficacy and economics of certain new generation novel insecticides against legume pod borer, Maruca vitrata (Geyer) on pigeonpea (Cajanus cajan L.). J App Biol Biotech. 2015; 3 (03): 007-010. 